\title{
Setting the Stage for Service Experience: Design Strategies for Functional Services
}

\author{
Ahmad Beltagui \\ University of Wolverhampton \\ Wolverhampton, U.K. \\ a.beltagui@wlv.ac.uk \\ Marina Candi* \\ Reykjavik University Center for Research on Innovation and Entrepreneurship \\ Menntavegur 1, 101, Reykjavik, Iceland \\ marina@ru.is \\ Johann C.K.H. Riedel \\ Nottingham University Business School, University of Nottingham \\ Jubilee Campus, Wollaton Road, Nottingham, NG8 1BB, U.K. \\ johann.riedel@nottingham.ac.uk
}

*corresponding author

\section{Acknowledgement}

Part of the funding for this work has been provided from the European Union's Seventh Framework Programme for research, technological development and demonstration under grant agreements no. 251383 and 324448 as well as the UK Design Performance project (AH/E507662/1). 


\begin{abstract}
Purpose-This research identifies service design strategies to improve outcome-oriented services by enhancing consumers' emotional experience, while overcoming customer variability.

Design/methodology/approach—An abductive, multiple-case study involves 12 service firms from diverse online and offline service sectors.

Findings-Six service design strategies represent two overarching themes: Customer empowerment can involve design for typical customers, visibility, and community building, while customer accommodation can involve design for personas, invisibility, and relationship building. Using these strategies helps set the stage for a service to offer an emotional experience.

Research limitations/implications-The study offers a first step toward combining investigations of service experience and user experience. Further research can strengthen these links.

Practical implications-The six design strategies described using examples from case research offer managerial recommendations. In particular, these strategies can help service managers address the customer-induced variability inherent in services.

Originality/value - Extant studies of experience staging have focused on particular sectors such as hospitality and leisure; this study contributes by investigating outcome-focused services and identifying strategies to create unique experiences that offset variability. It also represents a rare effort to combine research from service management and interaction design, shedding light on the link between service experience and user experience.
\end{abstract}

Keywords-Service experience, Customer experience, Service design, Service management, Interaction design, Emotional design

Paper type-Research paper 


\section{Introduction}

Researchers contend that, following the move from a manufacturing to service economy, the next step is the experience economy (Grönroos and Helle, 2010; Matthyssens and Vandenbempt, 2010), in which businesses attend to the customer experience to survive in crowded markets (e.g. Pine and Gilmore, 1999; Grewal et al., 2009). Focusing on customer experience addresses the risk of commoditization by designing services that offer symbolic or emotional value (Norman, 2004; Verganti, 2009; Candi and Saemundsson, 2011). However, most businesses find it challenging to do this.

In the experience economy, the most effective strategy is not routinized consistency, as exemplified by McDonald's (Levitt, 1972), but rather an emphasis on the customer experience, as exemplified by Walt Disney theme parks (Kingman-Brundage, 1991; Chase and Apte, 2007). Services have been reconceived as theater (Grove et al., 1992) and firms as using "services as the stage, and goods as props, to engage individual customers in a way that creates a memorable event" (Pine and Gilmore, 1998, p. 98). Memorable experiences create emotional bonds that lead to customer loyalty and improved business performance (Brakus et al., 2009; Candi et al., 2013). Scholars thus suggest that the service experience is what separates excellent service providers from average ones (Edvardsson et al., 2005).

Service researchers consider the experience economy a priority (e.g. Roth and Menor, 2003; Chase and Apte, 2007). They have investigated the topic through studies of experience-centric services, that is, services whose core offering is an experience (e.g., Pullman and Gross, 2004; Stuart and Tax, 2004). Zomerdijk and Voss (2010) investigate design consultancies employed by experience-centric service providers such as sports, leisure, and travel. The design practices they identify, such as focusing on the dramatic structure of events and delineating front- and back-stage areas, follow the "service as theater" metaphor, creating memorable experiences by appealing to customers on an emotional rather than a rational level.

However, these studies emphasize experience-centric rather than outcome-oriented services. In contrast, this research focuses on how the benefits of experience staging can be achieved in outcomeoriented services, referred to herein as experiential augmentation.

Service researchers have long been concerned with the customer experience, particularly in traditional, face-to-face contexts. Although the user experience in online services has become well established in computer science and interaction design, service research has paid considerably less attention to this concept. The user experience is important to designers because "the product does not exist in a vacuum. It becomes meaningful only in relation to a user" (Margolin, 1997, p. 229) - a view that parallels the concept of experience as co-created value (Vargo and Lusch, 2008). Similarly, though cocreation results from customers' interactions with value propositions, interaction designers recognize that "one cannot design an experience ... but only create the design features that evoke it" (Rogers et al., 2012, p.14). The goal of interaction design is to connect design features to users through psychological concepts such as affordances (Pucillo and Cascini, 2014), which are based on the understanding that design decisions afford, or facilitate, users' actions. For example, in online contexts, text underlined in blue is recognizable as a hyperlink that affords action. With few exceptions (e.g. Patricio et al., 2008; Wetter-Edman et al., 2013), however, discourses on user experience and customer experience remain entirely separate. As a first step toward finding common ground, the current research compares and contrasts cases of online and offline services.

The underlying assumption of this research is that the experience economy is not only relevant for experience-centric services but can also improve the competitiveness of more outcome-oriented services through experiential augmentation (Candi et al., 2013). This research in turn contributes practical guidance for businesses outside the experience economy (i.e. in sectors such as entertainment, travel, and hospitality, which are usually investigated in experience research (Lemke et al., 2011). An obvious but arguably expensive way to achieve this augmentation is to employ experience design consultancies (Zomerdijk and Voss, 2010; 2011). In contrast, the current research 
examines how firms that do not use professional experience design consultancies can augment their own services to improve the experience. A multiple case study of 12 service providers identifies service design strategies used to set the stage for service experience. This contribution is particularly novel in that it combines service research and design research perspectives and examines online and offline service contexts to identify opportunities for cross-fertilization, which is a particularly relevant topic because few service businesses rely solely on either online or offline channels.

The six service design strategies identified represent two overarching themes: accommodating customers and empowering customers to co-create positive service experiences. These can be used to enhance online and offline services, helping to overcome customer variability. The following sections explore the theoretical underpinnings of this research, outline the abductive case study method used, report the findings, and discuss theoretical and practical implications.

\section{Conceptual Background}

\subsection{Services and Value}

Central to the understanding of service and experience is the concept of value. Current perspectives of value challenge the assumption that value is created by firms and consumed by customers and instead emphasize the co-creation that occurs when customers' resources are combined with firms' value propositions to form an experience (Prahalad and Ramaswamy, 2004; Vargo and Lusch, 2008; Chandler and Lusch, 2015). This corresponds to Sampson's (2000) view of services as bidirectional supply chains, wherein customers supply inputs to the service process.

Service providers can take one of two stances to create value: They can deliberately involve customers in the definition, development, and refinement of the service experience, or they can anticipate and accommodate customers' needs and wishes through proactive experience staging. Either way, the result is a unique experience for each customer, depending on the resources integrated and both service and customer characteristics (Gentile et al., 2007; Verhoef et al., 2009).

Pine and Gilmore (1998) argue that experiences represent higher value offerings than products or services. This conception of value takes the perspective of the firm but does not reflect value for the customer (Payne and Holt, 2001). The current research addresses this gap by conceptualizing customer value as the outcome of services. As Abbott (1955, p. 40) argues, "what people really want are not products, but satisfying experiences."

Thus, this research acknowledges that services are co-created with customers, resulting in experiences that are unique to each customer. The value of these experiences can be created in active collaboration with customers or by proactively anticipating and accommodating customers' needs.

\subsection{Service Design}

Designers have changed their focus, shifting the object of their work from products to users (Redström, 2006). Design traditionally influences an artifact's characteristics while experiential augmentation aims to influence the people who buy or use something. This change of perspective is in line with theoretical discussions of the importance of value in use. In other words, the traditional perspective of value being created by firms has given way to an appreciation that firms offer value propositions but do not have full control over the creation of value in use. They set the stage for experiences, but the experience itself is created in and resides in customers' minds. The service encounter can be scripted, but the customer does not always follow the script (Tansik and Smith, 2000; Zomerdijk and Voss, 2010).

Service design must recognize the fundamental inability to plan and regulate services completely (Meroni and Sangiorgi, 2011). This research identifies service design strategies that can be used to set the stage for service experience, while also acknowledging that the service experience cannot be fully controlled. 


\subsection{Experiential Augmentation}

A service offering consists of a bundle of components that deliver functional or emotional value. Functional value relates to specific goals and typically can be evaluated before purchase (Roos and Friman, 2008; Puccinelli et al., 2009). Emotional value is experienced during the interaction between a customer and a service provider and therefore is assessed only during or after use (Hume et al., 2006). Other research distinguishes these two types of value as explicit and implicit (Sasser et al., 1978) or outcomes and experiences (Johnston and Kong, 2011). Holbrook (2006) suggests too much emphasis is placed on functional outcomes as a result of viewing humans as rational information processors, not unlike computers. In contrast, in earlier work (e.g. Holbrook and Hirschmann, 1982) he argues that a service can achieve functional outcomes while still delivering an emotionally satisfying experience. Lovelock (1995) notes that the service package can be viewed in terms of a core and an array of other elements that represent the augmentation. Particularly in mature service industries, the core can become commoditized, so the augmentation becomes a potential place to provide differentiation and competitive advantage (Candi and Saemundsson, 2011).

Experience-centric services (e.g., theater or circus performances) are those in which the experience is central; the experience is the service. However, outcome-oriented services can also make use of experience design to augment their core utilitarian offering (Beltagui et al., 2012). Scholars argue that service managers should pay attention to customers' experience, because it affects perceived service quality (Berry et al., 2002; Johnston et al., 2011). In one of the few empirical studies on the topic, Candi et al. (2013) demonstrate that experiential augmentation of services helps attract new customers.

In summary, the performance of outcome-oriented services can potentially be improved by designing for experience, and the purpose of this research is to identify service design strategies that can be used to this end.

\section{4. $\quad$ Research Questions}

Although services (and thus experiences) are not pre-produced offerings (Chandler and Lusch, 2015) that can be designed like tangible products, they consist of systems of interactions that can be positively influenced through appropriate design (Ding et al., 2010). Firms stage the prerequisites for an experience through service design, but the experience itself happens in customers' minds and research on the antecedents of successful experiences is needed (Roth and Menor, 2003). Perhaps the most important research contribution to date involves service mapping tools (Kingman-Brundage, 1991; Johnston, 1999) that shift the focus from the service provider to the customer's experience; that is, they encourage managers to consider moments in the customer's journey (e.g. Carlzon, 1987) rather than touchpoints defined from the service provider's perspective. These tools have been used to assess the positive and negative emotional impacts of service encounters, as seen through customers' eyes. For the service provider, a service consists of a series of elements that have been designed, including facilities, employees' roles, and the tasks and processes they perform (Beltagui et al., 2015). These elements are ideally designed according to service characteristics with an efficiency aim (Zomerdijk and De Vries, 2007; Ponsignon et al., 2011). For the customer, an experience consists of the overall emotional effect created (Goldstein et al., 2002). Therefore, an approach to service design that incorporates the customer experience in design decisions is necessary. The first question driving this research thus asks, what service design strategies can service providers use to augment their services with experience?

Service designers and managers face the challenge of customer variability (Morris and Johnston, 1987). Whereas operations managers generally seek to reduce variability and use standardization to manage quality, recognizing customers as active participants in the co-creation of value means acknowledging variability. Frei (2006) argues that though a positive service experience usually is considered at odds with efficient service, this does not have to be the case. In contrast with traditional approaches to variability, such as accommodation (improving experience but raising costs) and reduction (lowering costs but harming the experience), she proposes alternatives such as self-service, 
low-cost labor, and market segmentation. Thus the second research question asks, what service design strategies can help cope with different degrees of customer variability?

Fitzsimmons et al. (2014) suggest that an experience demands the customer's physical presence, as reflected in recommendations to create a theme or focus on sensory stimulation (Pine and Gilmore, 1999). Situated cognition explains the customer experience in terms of interaction with the environment (Suchman, 1987; Gupta and Vajic, 2000). Thus, a phenomenological examination of the experience typically considers the individual's awareness of his or her own embodiment within the environment, which is a human perception produced by consolidating sensory information (Joy and Sherry, 2003).

Online interactions take place through websites rather than physical facilities. In this context, the technical interface represents the stage, which makes staging an experience using structural elements (e.g. sensory design of facilities) difficult. When interaction with a service is mediated by technology, such as the Internet, a human connection is largely lacking. Researchers have raised concerns about the depersonalization of services (Forman and Sriram, 1991) caused by the use of technology in the interest of efficiency. According to Froehle and Roth (2004), the goal of the technology-mediated service experience ultimately is to match that of natural, face-to-face interaction. This dilemma leads to the third research question: Which service design strategies can be applied to both services delivered online and services delivered offline?

\section{Research Method}

This research uses a multiple case study to examine approaches to experience staging and synthesize a set of design strategies. Case studies allow consideration of context, because they permit a holistic view of phenomena, and multiple case studies make it possible to develop insights through comparison (Ragin, 2014).

Rather than a deductive or inductive approach, this research adopts abductive logic proposed by Charles Sanders Peirce (1931), which focuses not on what is true but what might be (Martin, 2009). Qualitative data are typically generated rather than collected (Gummesson, 1985). In other words, answers are not merely waiting for researchers to discover them. Rather, they form pieces of a jigsaw puzzle, in which the pattern appears gradually and guides the selection of the next piece. Building on this metaphor, the two main challenges of abductive case research are matching empirical pieces to theoretical patterns and redirecting enquiries as the image in the puzzle emerges (Dubois and Gadde, 2002). Figure 1 presents the evolution of the current study through several stages with continuous back-and-forth interaction between data and theory (Järvensivu and Törnroos, 2010). The theoretical framework, empirical fieldwork, and case analysis evolved simultaneously as the research progressed (Dubois and Gadde, 2002). Although these characteristics of abductive research make it challenging to perform and describe, the approach ultimately combines understanding of social actors' accounts of a situation while developing and testing models that can inform theory and practice (Blaikie, 2000). 


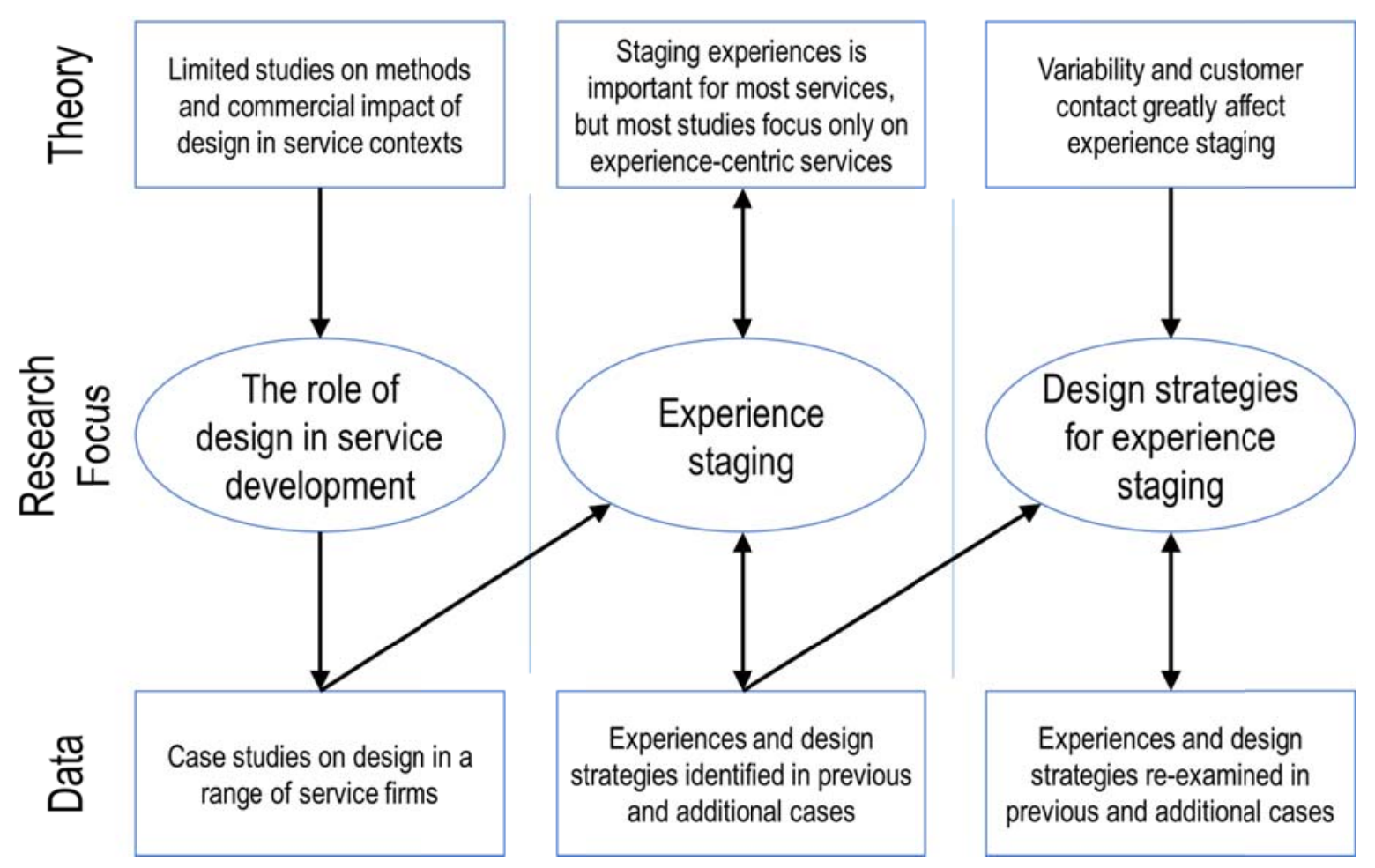

Figure 1 - The research followed an abductive process of moving between theory and data

\subsection{Case Selection and Data Generation}

Cases were selected using theoretical sampling; meaning that their ability to provide insights into the topic of interest and to offer contrasts was paramount rather than their representativeness (Eisenhardt, 1989; Yin, 2003). Table 1 presents a summary of the firms included in the study. Semi-structured interviews with key informants (managing directors, innovation managers, or service development managers) in each case firm provided the data. Roles and titles varied, as did the number of informants, depending on the size and nature of the firms. Observations during visits and examination of documents and websites further developed the cases. Employee behavior, environmental appearance, and website usability all contribute to the experience; thus, these observations and examinations were particularly relevant. Cases were chosen through personal networks and recommendations, providing some prior understanding of suitability to shed light on the topic (Miles and Huberman, 1994). In line with the abductive approach, this topic evolved over the course of the research.

Initially, cases were selected to learn about the use of design in service innovation. Interview questions focused on identifying the types of design used and their impact on the firm's success. For example, how aesthetic design was applied to the creation of environments or documents in a firm and the perceived effect that this design had on customers, employees, and overall commercial success represented key elements. In this stage, the study was guided by research into the commercial value of design (e.g., Roy and Riedel, 1997), which although it has been studied extensively, is still not well understood in service innovation contexts (Candi, 2016).

An emerging theme was the effect of design on the service experience. The focus consequently shifted to understanding experience design, with new cases added and previous cases reexamined. In this second stage, the study was guided by literature on service experience. Cases were selected in this stage to add to our understanding of experience staging methods and provide more points of comparison. 
To compare design strategies and highlight the differences among the case firms, service management literature themes - and the issue of customer variability in particular-were emphasized. At this point, the split between online and offline services became more important to understand how different degrees of variability are managed. Services delivered online or offline offer different opportunities for sensory design. They also tend to enable different degrees of customer contact and customization through direct or technology-mediated communication (Froehle and Roth, 2004). Cases were reexamined or added once again, to suit this new focus and ensure a balance between online and offline services. 
Table 1: Case companies, their core service offerings, their experiential augmentations and service design strategies observed. Case company names are pseudonyms.

\begin{tabular}{|c|c|c|c|c|}
\hline $\begin{array}{l}\text { Case } \\
\text { company }\end{array}$ & $\begin{array}{l}\text { Service } \\
\text { delivery }\end{array}$ & Core Service Offering & Experiential Augmentation & $\begin{array}{l}\text { Observed } \\
\text { design } \\
\text { strategies }\end{array}$ \\
\hline Daisy & Offline & $\begin{array}{l}\text { Shop selling art and } \\
\text { creative items by local } \\
\text { artists. }\end{array}$ & $\begin{array}{l}\text { Organising experiences (events), } \\
\text { such as having artists working in the } \\
\text { shop during opening hours. }\end{array}$ & $\begin{array}{l}\text { Design for } \\
\text { visibility }\end{array}$ \\
\hline $\begin{array}{l}\text { Expert } \\
\text { Info }\end{array}$ & Offline & $\begin{array}{l}\text { Workspace design and } \\
\text { installation as part of } \\
\text { facilities management for } \\
\text { a large financial services } \\
\text { company }\end{array}$ & $\begin{array}{l}\text { Emphasis on employee well-being } \\
\text { and productivity rather than purely } \\
\text { rational/efficiency concerns. }\end{array}$ & $\begin{array}{l}\text { Relationship } \\
\text { building }\end{array}$ \\
\hline Neutrino & Offline & $\begin{array}{l}\text { Custom development of } \\
\text { immersive 3D graphical } \\
\text { simulations for the } \\
\text { defence market. }\end{array}$ & $\begin{array}{l}\text { Realism is emphasized in the design } \\
\text { of the simulated virtual } \\
\text { environments while technical } \\
\text { details are hidden from customers. }\end{array}$ & $\begin{array}{l}\text { Design for } \\
\text { invisibility }\end{array}$ \\
\hline $\begin{array}{l}\text { Perfect } \\
\text { Peach }\end{array}$ & Offline & $\begin{array}{l}\text { Web development } \\
\text { services for individual and } \\
\text { corporate clients }\end{array}$ & $\begin{array}{l}\text { "Designer" office with integral } \\
\text { customer sales meeting room (with } \\
\text { glass window onto employee } \\
\text { workstations). }\end{array}$ & $\begin{array}{l}\text { Design for } \\
\text { invisibility } \\
\text { Design for } \\
\text { visibility }\end{array}$ \\
\hline $\begin{array}{l}\text { Tiling } \\
\text { House }\end{array}$ & Offline & $\begin{array}{l}\text { Retailing and wholesaling } \\
\text { of floor and wall tiles. }\end{array}$ & $\begin{array}{l}\text { Providing a kitchen and bathroom } \\
\text { design service to time-poor, cash- } \\
\text { rich consumers in a design studio } \\
\text { sales room. }\end{array}$ & $\begin{array}{l}\text { Relationship } \\
\text { building } \\
\text { Design for } \\
\text { visibility }\end{array}$ \\
\hline Aqua & Online & $\begin{array}{l}\text { Multimedia authoring } \\
\text { software applications } \\
\text { (service delivered online) }\end{array}$ & $\begin{array}{l}\text { Usability, ease of use; an online } \\
\text { forum, allowing communication } \\
\text { between customers and sharing } \\
\text { their expertise thence creating a } \\
\text { community. }\end{array}$ & $\begin{array}{l}\text { Community } \\
\text { building }\end{array}$ \\
\hline Blue fish & Online & $\begin{array}{l}\text { Hosted spam filtering } \\
\text { service }\end{array}$ & $\begin{array}{l}\text { Placing a computer at the } \\
\text { customers' premises with flashing } \\
\text { lights indicating that the service is } \\
\text { working. }\end{array}$ & $\begin{array}{l}\text { Design for } \\
\text { invisibility } \\
\text { Design for } \\
\text { visibility }\end{array}$ \\
\hline $\begin{array}{l}\text { Certain } \\
\text { Games }\end{array}$ & Online & $\begin{array}{l}\text { Independent software } \\
\text { development firm, } \\
\text { developing online casual } \\
\text { games for a media } \\
\text { company and managing } \\
\text { the community of players. }\end{array}$ & $\begin{array}{l}\text { Online interaction between } \\
\text { customers helps to foster a sense of } \\
\text { community, both in playing the } \\
\text { games but also in sharing } \\
\text { information and voluntarily } \\
\text { assisting fellow customers. Some } \\
\text { customers volunteer to help plan } \\
\text { and manage tournaments. }\end{array}$ & $\begin{array}{l}\text { Design for } \\
\text { personas } \\
\text { Community } \\
\text { building }\end{array}$ \\
\hline E-docs & Online & $\begin{array}{l}\text { Document compliance } \\
\text { system for storing and } \\
\text { processing hospitals' } \\
\text { medical documents }\end{array}$ & $\begin{array}{l}\text { Simplification through complexity- } \\
\text { hiding. }\end{array}$ & $\begin{array}{l}\text { Design for } \\
\text { typical } \\
\text { customer } \\
\text { Design for } \\
\text { invisibility }\end{array}$ \\
\hline M-Blog & Online & $\begin{array}{l}\text { Service for estate agents } \\
\text { for posting photos from } \\
\text { mobile phones on to the } \\
\text { Internet. }\end{array}$ & $\begin{array}{l}\text { Simplification of a traditionally } \\
\text { complex and time-consuming task. }\end{array}$ & $\begin{array}{l}\text { Design for } \\
\text { typical } \\
\text { customer }\end{array}$ \\
\hline
\end{tabular}




\begin{tabular}{lllll}
\hline $\begin{array}{l}\text { Case } \\
\text { company }\end{array}$ & $\begin{array}{l}\text { Service } \\
\text { delivery }\end{array}$ & Core Service Offering & Experiential Augmentation & $\begin{array}{c}\text { Observed } \\
\text { design } \\
\text { strategies }\end{array}$ \\
\hline Plinx & Online & $\begin{array}{l}\text { Online music sharing and } \\
\text { community for “garage } \\
\text { bands" and music lovers. }\end{array}$ & $\begin{array}{l}\text { Customer control over } \\
\text { customization and community } \\
\text { among customers. }\end{array}$ & $\begin{array}{c}\text { Design for } \\
\text { personas }\end{array}$ \\
\hline Valy & Online & $\begin{array}{l}\text { Web site development } \\
\text { and hosting services } \\
\text { allowing customers to } \\
\text { design their own } \\
\text { websites, based on } \\
\text { templates. }\end{array}$ & $\begin{array}{l}\text { Emphasis on simplicity and } \\
\text { convenience, hiding what } \\
\text { customers see as technically } \\
\text { unfamiliar and empowering them to } \\
\text { create their own websites. }\end{array}$ & Design for \\
invisility
\end{tabular}

\subsection{Data analysis}

Case summaries and initial interpretations were prepared using interviews, field notes, and other available data. Informants received the summaries and were invited to provide feedback, including corrections of any misunderstandings and additional details. These steps are important to help ensure that the qualitative accounts are trustworthy and fair to participants (Lincoln and Guba, 1985; Lincoln et al., 2011).

The analysis proceeded in two stages: first within and then between cases (Voss et al., 2003). Design strategies were identified through within-case analysis, which sought to understand the context and approaches to design that had been used in each case. Next, the between-case analysis involved research team meetings to examine and compare cases (Miles and Huberman, 1994), by classifying the "whats" (description of experience), "whys" (motivation for experience staging), and "hows" (design strategies) to extract the design strategies. The analysis was repeated as the literature review was refocused and new cases were added, as shown in figure 2.

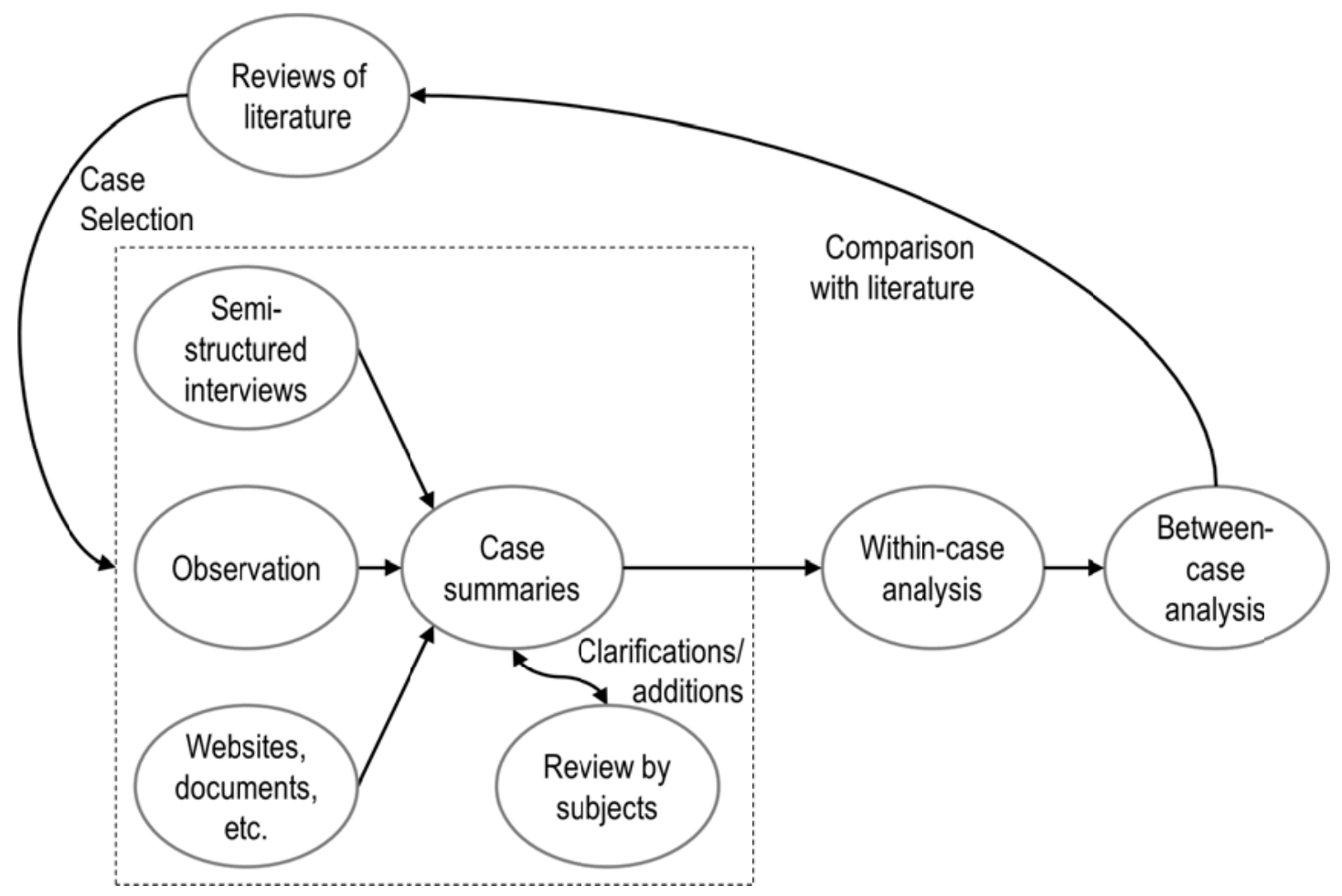

Figure 2 - An iterative process of case selection, data generation and analysis

An example of a design strategy is design for visibility, which arose in the Blue Fish case. The firm made a taken-for-granted service more visible through a physical reminder. Although initially 
identified as a physical cue included in the service design, the concept expanded when similar (Perfect Peach making the workplace more visible to customers) and contrasting (attempts to hide the complexity in several cases) design strategies emerged in other cases.

\section{Findings}

The case firms exemplified six service design strategies used to achieve experiential augmentation, as summarized in Table 1. The following subsections discuss each of these design strategies in detail.

\subsection{Design for a Typical Customer}

A service can be designed through close interaction with one customer, viewed as typical of other customers. E-docs and M-blog implemented this involvement of a single customer.

The development of E-docs' service involved close collaboration with one customer for whom a high level of customization was required. Because this customer's functional needs matched those of other envisioned customers closely, the firm used those needs as a platform, supporting easier customization for subsequent customers. In describing this customization, E-doc's CEO explained, "We have a customer actually using the service while we develop it. And so we are continually listening to the problems that they have, wish lists, things like that."

Similarly, M-Blog's approach to understanding customers was to identify a representative customer and collaboratively develop the service for this customer's needs. In turn, M-Blog could understand the customer's processes and simplify their execution. After the initial customization, the service was launched as a generic online service. Due to the lack of variability among customers, selecting one customer as a representative was an effective approach to service design.

\subsection{Design for Personas}

Customers can be segmented according to their characteristics or the service outcomes they require. A persona is a profile of a customer, written as a kind of fictional character with a name and a life story. The characters are based on the available knowledge about customers, and their number can vary. For example, Certain Games and Plinx, both of which offer online services, design services for personas. They identified different types of customers and developed personas to characterize each type and describe their motivations. One of Certain Games' personas was described as a busy person who plays to unwind after work. This persona was given a fictional name and job, to help designers understand the persona as a method actor would attempt to get into character. As a Certain Games respondent noted, "We use personas, which are stories about imagined users, or users we know, that emphasize their characteristics and help us deliver a more relevant service. We start with an 'epic story' and then break it down into smaller, more detailed, stories." Plinx instead approaches personas systematically, using close observation of representative customers through online activity logs. User observations are combined with storyboarding, a technique adopted in collaboration with a filmmaking firm, to map the customer's journey as a graphical representation of a story, which enables a detailed first-person perspective when developing the service.

In contrast with design for personas, which addresses variability among customers by categorizing them, designing for a typical customer relies on the assumption that there is little or no variability among customers.

\subsection{Community Building}

Self-service typically entails passing the burden of carrying out tasks to the customer in an effort to reduce costs. Although cost-cutting may be viewed as detrimental to the experience if a trade-off between cost and quality occurs, self-service contributes to the experience in some cases, due to one crucial factor: communities. Being part of a community helps create a satisfying experience and taking more responsibility helps strengthen bonds within that community. For some case firms, such as 
Certain Games and Aqua, the main advantage of the community is that customers support one another. In general, accommodating a high level of variability in customer requests through more interactions with employees enhances the experience. However, empowering customers to help themselves and assist one another also can be a useful approach to achieve experiential augmentation.

Aqua offers its service on an online platform, meaning that customization for individuals and direct customer contact are both low. However, an online forum, allowing unmediated communication, facilitates contact among customers and the creation of a community. Community members share their expertise by responding to problems and supporting others - essentially, providing voluntary effort. A project manager at Aqua notes, "We have a web forum where they can post questions on-line. And the on-line forums are monitored by tech support as well as by QA and engineering, but most of the questions are actually answered by other users." Similarly, online interactions among Certain Games' customers helps foster a sense of community, in both game play and information sharing or voluntarily assisting fellow customers. Some customers volunteer to be supervisors to help plan and manage tournaments, prizes, and special events. The firm had previously sought to automate these tasks, but customers perform voluntarily to gain a feeling of control and a sense of purpose. Empowering these voluntary supervisors also helps resolve conflicts that arise between customers with different objectives and facilitates the staging of multiple experiences.

\subsection{Relationship Building}

Tiling House redesigned its retail space to create the feel of a design studio, and the firm clearly separates on-stage and off-stage areas to ensure that employees are part of what it has designed to feel like a theatrical performance. A key part of the staged experience is an emphasis on building relationships when employees personalize offerings through interaction with customers, that is, not selling tiles but designing kitchens or bathrooms in which the tiles will be used. To enable this, the firm hired interior designers as salespeople and trained existing sales staff in interior design. These staff members can collaboratively design bathrooms or kitchens with the customer and extend the scope from the sale of tiles to a complete solution for the design and installation of kitchens and bathrooms.

Expert Info, which designs working environments, developed an approach based on an empathic understanding of the people working in those environments. In addition to determining physical dimensions and technical specifications, the firm builds an emotional relationship to create improved working environments. Its success can be measured in the increased productivity resulting from these workplaces, in comparison with those designed from a purely functional perspective.

\subsection{Design for Visibility}

When a service is invisible to the customer (e.g. Stuart and Tax's [2004] cleaning service), subtle reminders or efforts to create visibility may be used to create an emotional impact. Although Perfect Peach and Blue Fish both aimed for invisibility in terms of hiding technical complexity, they also make efforts to provide customers with a glimpse of their inner workings. Perfect Peach's focus on the experience offered to customers helps create a strong impression of quality, reliability, and professionalism. Nowhere is this more evident than in the design of physical facilities, such as the interior design of the firm's office space. The firm has recently moved into a new facility and made substantial investments in creating a captivating space for customers. A glass wall separates the meeting room used for meetings with prospective customers from the busy workspace, creating visibility of the back office but also allowing customers to see employees working productively. The CEO noted that this design generated confidence among employees. Whereas previously, salespeople were more likely to visit customers, now "we always make an effort to bring the customer in here ... because it always results in a sale" as a result of the experience generated by the environment and well-rehearsed interaction styles with customers.

Blue Fish's expressed challenge was demonstrating the value of a service (e-mail security solution that filters unwanted spam messages from client systems) that is invisible unless it fails. The experiential 
augmentation observed in this case involved making this invisible service more visible to customers. First, Blue Fish issues regular reports to customers, presenting details about the number of threats detected and communicating the benefits that have been gained. Second, the firm placed a computer on each of its customers' premises with prominent flashing lights to communicate that this machine was actively providing protection, creating visibility and reminding customers of the service provided. Although neither of these approaches represents clearly unnecessary costs, their purpose is not functional; rather, they target the customer on a psychological or emotional level, creating an experience that influences their perceptions of service quality.

Daisy acts as a gallery, with a range of goods available for sale, but for revenue it relies on visitors ordering high-value, bespoke items from the artists. The firm regularly stages events and performances, inviting collaborating artists to exhibit their work. For example, a resident artist paints canvases onsite, which are then sold to customers. Such performances have the effect of revealing the process behind the products, as well as making the experience of shopping more unique and memorable.

Tiling House took the concept of visibility a step further by offering customers the possibility to participate in the design of their tiling installations, which represents a form of co-creation.

\subsection{Design for Invisibility}

Many of the case firms noted that when customers' abilities or willingness to spend effort are low, simplifying a service by hiding technical complexity can enhance the customer experience. For example, E-doc's service, which removes the burden of processing information and following regulations from customers, allows customers to focus on more important tasks.

Perfect Peach's employees must understand and deliver solutions to meet customers' needs. Their interactions with customers are not bound by formal scripts but instead are based on rules that offer a guide for how customers should be treated. The stated intention is to avoid technical jargon in conversation and documents, downplay technical expertise, and relate to customers in lay terms, which should foster a feeling of trust. Similarly, in Blue Fish, Valy, and Neutrino, a strong expressed sentiment focused on hiding complexity, referred to as invisibility. A product manager at Blue Fish thus described how "We wanted to have as few interaction idioms as possible that would still solve the problem. We actually aim for no interaction ... once you have a knob to tweak, it's basically admitting that your service is complex."

\subsection{Conclusion}

A prevailing sentiment in extant literature is that customer variability harms the quality of a service (Frei, 2006). The current research identifies two responses to this variability: customer accommodation and customer empowerment.

Customer accommodation involves carrying out additional work to create a unique experience for each customer. This approach usually results in additional costs or inefficiency but engenders unique and personal experiences. It depends on increasing contact with customers and developing an empathic understanding. Employee training and empowerment are necessary to ensure a workforce that is able to understand customer needs and act upon them. For customers who are cash rich but time poor, such as those targeted by Tiling House, this approach is ideal because it creates differentiation.

Another group of customers may be more price-sensitive and less willing to pay for someone to do work on their behalf. As Dong et al. (2014) note, some customers enjoy carrying out additional work or appreciate autonomy. These customers may prefer customer empowerment, which can contribute to both lower costs (Frei, 2006) and an improved experience. Giving customers the ability to customize the service can facilitate co-creation and make the service more democratic through user involvement (Björgvinsson et al., 2010; Junginger and Sangiorgi, 2011). Table 2 presents the six service design strategies identified in the case study, which fall under the two themes of accommodation and empowerment. 
Table 2: Service design strategies identified in the case firms, classified as strategies for customer empowerment or for customer accommodation.

\begin{tabular}{|c|c|}
\hline Customer Empowerment & Customer Accommodation \\
\hline Design for Typical Customer & Design for Personas \\
\hline $\begin{array}{l}\text { An individual customer, representative of the typical } \\
\text { customer, is used to understand the needs of } \\
\text { customers. The service is developed to meet the } \\
\text { needs of this individual on the assumption that this } \\
\text { will satisfy customers in general. }\end{array}$ & $\begin{array}{l}\text { A number of different types of customers are } \\
\text { identified, whose needs differ. A persona represents a } \\
\text { character description for each type of customer, } \\
\text { forcing service developers to consider the experience } \\
\text { for each character, not "the customer" or "the user". }\end{array}$ \\
\hline Community Building & Relationship Building \\
\hline $\begin{array}{l}\text { A standard offering is provided but customers are } \\
\text { able to modify it or assist others in doing so. This } \\
\text { assumes the customer gains emotional satisfaction } \\
\text { from performing such tasks or sharing their } \\
\text { expertise with others. }\end{array}$ & $\begin{array}{l}\text { Customers' requests are accommodated by employees } \\
\text { offering additional services. This assumes the } \\
\text { customer gains emotional satisfaction from being } \\
\text { treated as an individual and is willing to pay for the } \\
\text { effort of the service provider doing so. }\end{array}$ \\
\hline Design for Visibility & Design for Invisibility \\
\hline $\begin{array}{l}\text { Processes that are normally hidden in the back- } \\
\text { office are partially revealed to customers. This helps } \\
\text { customers to understand what they are paying for, } \\
\text { or enables their more active involvement. }\end{array}$ & $\begin{array}{l}\text { Tasks or processes that normally burden the customer } \\
\text { are simplified or removed from view. This helps the } \\
\text { customer to focus on what the service provides and } \\
\text { trust the service provider to understand how it is } \\
\text { achieved. }\end{array}$ \\
\hline
\end{tabular}

The first pair of strategies involves understanding and incorporating user needs: design for typical customer (empowering) and design for personas (accommodating). The use of personas is well established in interaction design. Interaction design focuses on understanding how humans understand and use artificial systems (e.g. Suchman, 1987), then designing these systems to fit their mental models. The field has evolved on the basis of the idea of emotional design - that is, the premise that things that customers love are more successful than those they merely tolerate (Norman, 2004). The methods employed, such as personas (Cooper, 2004), are an attempt to respond to the challenge of designing with little contact with the customer or end user. The use of personas may not be familiar to service managers who rely on market segmentation and average data on customer segments. The alternative approach relies on designing a service with a real customer that represents the needs of others (referred to as designing for a typical customer). This service is developed to fulfill one specific customer's needs, with the intention that minimal customization should be required for further customers. As with personas, the purpose should be to understand customer behavior to create a positive experience when the service fulfills its functions.

During service delivery, two approaches to communicating quality and results emerged: visibility (empowering) and invisibility (accommodating). Services are traditionally viewed as intangible processes and therefore typically concealed. However, we observed a clear scope for enhancing the experience by reducing or increasing this invisibility. One of the challenges of many outcome-oriented services is convincing customers of their quality. For example, in legal or health care services, the customer may not understand the service processes and probably is unable to judge quality until the outcome has been achieved (Harvey, 1998). A proposed solution is to deliberately include clues that demonstrate service quality. By concealing the complexity of back-office processes, a service provider can ensure that customers experience more convenience. Conversely, by revealing parts of the process, customers are given either visual clues or potentially the ability to co-create the service, as observed at Tiling House. Visibility may mean allowing customers to see what is happening to gain more understanding. The next level may be allowing customers to contribute to the service. Invisibility, in contrast, enhances the experience by hiding rather than revealing and doing more work so the customer does not have to expend effort. 
The experience consists of the customer's assessment of both the outcome and the emotional journey during service delivery (Hume et al., 2006; Johnston and Kong, 2011). Thus, even for outcomeoriented services, the emotional connection formed with the service provider is important. Managers can improve this connection through deliberate efforts to build relationships with customers (an accommodating strategy), particularly in offline services, in which well-trained employees who aim to ensure a positive experience meet customers face-to-face. This strategy is appealing but costly (Chase, 1981). A different challenge is how to achieve a similar effect for technology-mediated service encounters. One observed approach was to facilitate creation of a community in which relationships among customers could be built (an empowering strategy). Current thinking on the nature of service logic suggests that customers should not be seen as passive consumers but rather as active co-creators of value. Nowhere is this more visible than in communities in which customers interact and support one another to enhance their experience. Although this strategy can be used to reduce costs to the firm (e.g. minimizing Aqua's customer support cost by enabling users to share knowledge), it can also help create an experience. Therefore, in contrast with Froehle and Roth's (2004) view that technologymediated service encounters are less personal than face-to-face ones, using technology to create communities alters the dynamic by democratizing the service (Björgvinsson et al., 2010).

\section{Discussion}

\subsection{Implications for Theory}

For academics, this research links service marketing and service operations literature streams, noting the need to shift the service design perspective from focusing on the operation and its efficiency to accounting for customer experience (Roth and Menor, 2003; Chase and Apte, 2007). As acceptance of the service logic has become more widespread and competition in mature markets has become more challenging, the customer experience has become an essential concern for all services (Grewal et al., 2009). This perspective echoes the paradigm shift in marketing literature toward considerations of value in use and co-creation. It also connects with design literature, where a similar shift from focusing on products to focusing on experience is evident. By combining these theoretical approaches and observing real-life examples, this research contributes a set of service design strategies relevant for service operations, each of which attempts to deal with the issue of customer variability in some way. In addition, this research establishes some links among service operations, marketing, and interaction design, reflecting the need for more integrated, interdisciplinary research in the effort to understand service management.

This research also contributes to the understanding of service experience in two ways. First, its focus on service design strategies for augmenting a functional core service is novel. It builds on the recognition that experience is important and that experience staging, though challenging, brings economic benefits (Brakus et al., 2009; Candi et al., 2013). Second, by including online and offline services, this research makes a step toward bridging the gap between interaction design and service management. The need to consider customers and their subjective perceptions has long been central to service research but is now gaining more attention, particularly as existing understandings of service and business in general are reconceived. Experiential augmentation demands that the starting point for service development be customers and how they perceive services, which means understanding customers in terms of not only their goals and motivations but also their likely emotional reactions to services. In this respect, interaction design strategies, which are now commonly practiced in user experience design, may be extremely valuable. Approaches such as understanding users' emotional interactions with value propositions (Norman, 2004) begin with understanding users (Margolin, 1997) in terms of their emotional engagement and motivation (Cooper, 2004) and the related affordances that the design features allow (Pucillo and Cascini, 2014).

\subsection{Implications for Practice}

Arguably, the main practical contributions of existing research consist of tools for mapping customers' experiences (e.g. Kingman-Brundage, 1991; Johnston, 1999) and the identification of service elements 
that are under service providers' control and that can affect these experiences (Grewal et al., 2009; Zomerdijk and Voss, 2010; Beltagui et al., 2015). Mapping and awareness of how the elements of a service affect customer experience are important to further progress and practical guidance is needed with regard to how these service elements can be designed to achieve experiential augmentation.

Thus, for practitioners, the benefits of this research lie in the service design strategies identified. The findings offer both descriptions of the strategies observed and examples of where they can be beneficial. These insights are particularly relevant for outcome-oriented services, which can benefit from insights about how firms can create unique value propositions that lead to memorable experiences.

When managers seek to design new services or redesign existing ones, they normally deploy a range of established methods and strategies that focus on operational effectiveness and efficiency. For example, layouts are considered from the perspective of minimizing movement, locations for maximizing the catchment area, and processes for reducing waiting times. Entering the experience economy (Pine and Gilmore, 1998) may seem like a good idea in a time of economic plenty, when customers have money to spend on experiences. In times of economic hardship, however, experience is arguably even more important, because customers are more inclined to shop around (Grewal et al., 2009; Flint et al., 2014). Focusing on the customer experience can help firms compete by attracting and retaining customers from competing but undifferentiated services (Lovelock, 1995; Grewal et al., 2009; Candi and Saemundsson, 2011; Candi et al., 2013). The traditional approach is simply to offer a high level of customization and contact with customers, but managers need lower-cost alternatives as well (Maister and Lovelock, 1982; Frei, 2006).

This research demonstrates that experiential augmentation is relevant and valuable in many service contexts. It identifies effective service design strategies, regardless of the level of customer contact or degree of customization of their services. As such, it offers suggestions for how to build memorable experiences without incurring the high cost of accommodating customer variability. When variability among customers is low, it may be possible to identify a typical customer on which to focus. If variability is higher, it may be possible to define categories of different customers, in which case personas help create empathy with groups of customers and ensure that their experience, not just the functionality delivered, is considered. When customers are unaware of a service, visibility can be increased, whereas customers who are daunted by the complexity of a service can have a positive experience when invisibility is increased. When customers gain satisfaction from doing something for themselves and others, community building involves offering the appropriate resources to do so. In particular, creating or supporting customer communities can make self-service seem to be a positive experience, rather than a form of exploitation. In other cases, the inherent variability in customer needs is better served by adopting a strategy of relationship building to customize the service for each customer.

Managers should note that the choice of service design strategies is not necessarily mutually exclusive. That is, customer accommodation and customer empowerment can be used in relation to different parts of the service. For example, as discussed previously, Perfect Peach creatively espoused both invisibility (to hide complexity) and visibility (to expose inner workings).

Clear differences between online and offline contexts emerged, specifically between customer experience as defined in management literature and user experience as defined in design literature. The case research suggests that these differences should be overcome, because there is value in applying methods from one field to another. Table 3 provides a summary of the service design strategies identified and specific recommendations for services delivered in online and offline contexts. 
Table 3: Summary of service design strategies for experiential augmentation and their potential applications in online and offline contexts.

\begin{tabular}{lll}
\hline Method & $\begin{array}{l}\text { Recommendations for experiential } \\
\text { augmentation of services delivered online }\end{array}$ & $\begin{array}{l}\text { Recommendations for experiential } \\
\text { augmentation of services delivered offline }\end{array}$ \\
\hline $\begin{array}{l}\text { Design for } \\
\text { Typical }\end{array}$ & $\begin{array}{l}\text { Select a customer whose needs are } \\
\text { representative of others. Use this customer }\end{array}$ & $\begin{array}{l}\text { Identify a customer whose functional } \\
\text { requirements are representative of a } \\
\text { majority of customers and use them as the } \\
\text { as a focal point for developing the } \\
\text { functionality of the service. }\end{array}$ \\
& $\begin{array}{l}\text { bervice. Ensuring usability for this individual } \\
\text { customer should increase the likelihood that } \\
\text { others benefit from the service. }\end{array}$ \\
\hline
\end{tabular}

\begin{tabular}{ll}
\hline Design for & Use available information about customers to \\
Personas & $\begin{array}{l}\text { create personas that explain the behavior } \\
\text { and goals of customer archetypes. }\end{array}$
\end{tabular}

Use personas as a design tool and as an alternative to market segmentation. Available information about potential customers can be used to develop an archetypal persona, whose needs can be addressed.

\begin{tabular}{lll}
\hline $\begin{array}{l}\text { Community } \\
\text { Building }\end{array}$ & $\begin{array}{l}\text { Design services to enable customers to do } \\
\text { their own customization. Make use of } \\
\text { communities to offer support to other } \\
\text { customers. }\end{array}$ & $\begin{array}{l}\text { Design the service to allow customers to do } \\
\text { their own customization, without requiring } \\
\text { input from employees, making self-service } \\
\text { positive. Building or supporting communities } \\
\text { can help to facilitate this. }\end{array}$ \\
\hline $\begin{array}{lll}\text { Relationship } \\
\text { Building }\end{array}$ & $\begin{array}{l}\text { While the appeal of the Internet may be that } \\
\text { it reduces the cost and time involved in } \\
\text { personal contact, some customers may } \\
\text { appreciate having someone to talk to or to go } \\
\text { to for help. Services delivered online could } \\
\text { examine ways to enable more personal } \\
\text { interaction and customization. }\end{array}$ & $\begin{array}{l}\text { Develop employees' abilities to customize } \\
\text { solutions for each customer and make use of } \\
\text { direct interaction to add value to the service. }\end{array}$ \\
\hline $\begin{array}{l}\text { Design for } \\
\text { Visibility }\end{array}$ & $\begin{array}{l}\text { Provide tangible evidence of otherwise } \\
\text { invisible services. Make processes and } \\
\text { software code available for customers to } \\
\text { modify themselves. }\end{array}$ & $\begin{array}{l}\text { Allow customers to see (parts of) back-office } \\
\text { processes, to help them appreciate the value } \\
\text { of what they are buying. }\end{array}$ \\
\hline $\begin{array}{l}\text { Design for } \\
\text { Invisibility }\end{array}$ & $\begin{array}{l}\text { Hide technical complexity by carrying out } \\
\text { processes independently of customers. } \\
\text { Reveal only high level information that is } \\
\text { required by customers. }\end{array}$ & $\begin{array}{l}\text { Make the service easier for customers to } \\
\text { understand by focusing on inputs and } \\
\text { outputs, while hiding technical processes. }\end{array}$ \\
\hline
\end{tabular}

\subsection{Limitations and Directions for Further Research}

This research identifies design strategies across a number of contexts. In seeking commonalities, it is less concerned with the unique characteristics of each context. Consequently, future research could expand on the managerial guidelines by developing a more comprehensive contingency approach that would help managers and designers select the context-appropriate strategies. The diversity in contexts makes direct performance comparisons infeasible, but future research could contribute to management practice by comparing the success of different strategies and in different contexts.

The research attempts to bridge the gap between discussions of customer experience in service management and user experience in service design. The differences are evident from the literature review and represented by the strategies identified in online services, which emphasize user 
experience and offline services, which emphasize customer experience. By examining the managerial challenge of variability, this study illustrates the need to incorporate the perspectives of customers and users alongside those of managers and designers. A suggestion for future research is to ensure a stronger cross-disciplinary focus, as the design perspective can enrich research and practice in service management.

Finally, further research should address the distinction between experience-centric and outcomefocused services. Most existing experience-related studies focus mainly on services for which the experience is the outcome. The current research identifies design strategies that apply when the experience can augment the outcome. A next step is to examine the extent to which these strategies work in experience-centric as well as outcome-oriented services.

\section{References}

Abbott, L. (1955), Quality and Competition: an essay in economic theory. New York: Columbia University.

Beltagui, A., Candi, M. and Riedel, J.C.K.H. (2012), "Design in the experience economy", in Zou, S. and Swan, S. (eds.), Interdisciplinary Approaches to International Marketing: Creative Research on Branding, Product Design/Innovation, and Strategic Thought/Social Entrepreneurship, Advances in International Marketing Series, Vol. 23, Emerald, UK.

Beltagui, A., Darler, W. and Candi, M. (2015) "Measuring the Deliverable and Impressible Dimensions of Service Experience." Creativity and Innovation Management, Vol. 24, No. 3, pp. 478-492.

Berry, L.L., Carbone, L.P. and Haeckel, S.H. (2002), "Managing the total customer experience", MIT Sloan Management Review, Vol. 43, No. 2, pp. 85-89.

Björgvinsson, E., Ehn, P. and Hillgren, P. (2010), Participatory design and "democratizing innovation", PDC 2010, Sydney, Australia, 29th November.

Blaikie, N.W.H. (2000), Designing social research: the logic of anticipation, Oxford: Blackwell.

Brakus, J.J., Schmitt, B.H. and Zarantonello, L. (2009), "Brand experience: what is it? How is it measured? Does it affect loyalty?", Journal of Marketing, Vol. 73, No. 3, pp. 52-68.

Candi, M. (2016), "Contributions of design emphasis, design resources and design excellence to market performance in technology-based service innovation", Technovation, Vol. 55-56, pp. 3341.

Candi, M., Beltagui, A. and Riedel, J.C. (2013), "Innovation through experience staging: Motives and outcomes", Journal of Product Innovation Management, Vol. 30, No. 2, pp. 279-297.

Candi, M. and Saemundsson, R. (2011), "Exploring the Relationship Between Aesthetic Design as an Element of New Service Development and Performance", Journal of Product Innovation Management, Vol. 28, No.4, pp. 536-557.

Carlzon, J. (1987), Moments of truth, Ballinger, Cambridge, MA.

Chandler, J.D. and Lusch R.F. (2015), "Service Systems: A Broadened Framework and Research Agenda on Value Propositions, Engagement, and Service Experience", Journal of Service Research, Vol. 18, No. 1, pp. 6-22.

Chase, R.B. (1981), "The customer contact approach to services: theoretical bases and practical extensions", Operations Research, Vol. 29, No. 4, pp. 698-706. 
Chase, R.B. and Apte, U.M. (2007), "A history of research in service operations: what's the big idea?”, Journal of Operations Management, Vol. 25, No. 2, pp. 375-386.

Cooper, A. (2004), The inmates are running the asylum, Sams, Indianapolis.

Ding, D.X., Hu, P.J., Verma, R. and Wardell, D.J. (2010), “The Impact of Service System Design and Flow Experience on Customer Satisfaction in Online Financial Services", Journal of Service Research, Vol. 13, No. 1, pp. 96-110.

Dong, B., Sivakumar, K., Evans, K.R. and Zou, S. (2014), "Effect of Customer Participation on Service Outcomes: The Moderating Role of Participation Readiness", Journal of Service Research, Vol. 18, No. 2, pp. 160-176.

Dubois, A. and Gadde, L-E. (2002), "Systematic combining: an abductive approach to case research." Journal of Business Research, Vol. 55, No. 7, pp. 553-560.

Edvardsson, B., Enquist, B. and Johnston, R. (2005), "Cocreating Customer Value Through Hyperreality in the Prepurchase Service Experience", Journal of Service Research, Vol. 8, No. 2, pp. 149-161.

Eisenhardt, K.M. (1989), "Building theories from case study research", Academy of Management Review, Vol. 14, No. 4, pp. 532-550.

Fitzsimmons, J., Fitzsimmons, M.J. and Bordoloi, S.K. (2014), Service Management: Operations, Strategy, Information Technology, $8^{\text {th }}$ edition, McGraw-Hill, New York, NY.

Forman, A.M. and Sriram, V. (1991), “The depersonalization of retailing: Its impact on the 'lonely' customer", Journal of Retailing, Vol. 67, No.2, pp. 226-243.

Flint, D.J., Lusch, R.F. and Vargo, S.L. (2014), "The supply chain management of shopper marketing as viewed through a service ecosystem lens", International Journal of Physical Distribution \& Logistics Management, Vol. 44, No. 1-2, pp. 23-38.

Frei, F.X. (2006), "Breaking the trade-off between efficiency and service", Harvard Business Review, Vol. 84, No. 11, pp. 92-101.

Froehle, C.M. and Roth A.V. (2004), "New measurement scales for evaluating perceptions of the technology-mediated customer service experience", Journal of Operations Management, Vol. 22, No. 1, pp. 1-21.

Gentile, C., Spiller, N. and Noci, G. (2007), "How to sustain the customer experience: an overview of experience components that co-create value with the customer", European Management Journal, Vol. 25, No. 5, pp. 395-410.

Goldstein, S.M., Johnston, R., Duffy, J. and Rao, J. (2002), “The service concept: the missing link in service design research?” Journal of Operations Management, Vol. 20, No.2, pp. 121-134.

Grewal, D., Levy, M. and Kumar, V. (2009), "Customer experience management in retailing: an organizing framework", Journal of Retailing, Vol. 85, No. 1, pp. 1-14.

Grove, S.J., Fisk, R.P. and Bitner, M.J. (1992), "Dramatizing the service experience: a managerial approach”, Advances in services marketing and management, Vol. 1, No.1, pp. 91-121.

Grönroos, C. and Helle, P. (2010), "Adopting a service logic in manufacturing: Conceptual foundation and metrics for mutual value creation", Journal of Service Management, Vol. 21, No. 5, pp. 564590.

Gummesson, E. (2000), Qualitative methods in management research, London: Sage Publications. 
Gupta, S. and Vajic, M. (2000), "The contextual and dialectical nature of experiences", in Fitzsimmons, J.A. and Fitzsimmons, M.J. (eds.), New service development: creating memorable experiences, Sage, London.

Harvey, J. (1998), "Service quality: a tutorial", Journal of Operations Management, Vol. 16, No. 5, pp.583-597.

Holbrook, M.B. (2006), "Consumption experience, customer value, and subjective personal introspection: An illustrative photographic essay", Journal of Business Research, Vol. 59, No. 6, pp. 714-725.

Holbrook, M. B., \& Hirschman, E. C. (1982). "The experiential aspects of consumption: Consumer fantasies, feelings, and fun.” Journal of Consumer Research, Vol. 9, No. 2, pp.132-140.

Hume, M., Mort, G.S., Liesch, P.W. and Winzar, H. (2006), "Understanding service experience in non-profit performing arts: implications for operations and service management", Journal of Operations Management, Vol. 24, No. 4, pp. 304-324.

Järvensivu, T. and Törnroos, J.Å. (2010), "Case study research with moderate constructionism: Conceptualization and practical illustration.” Industrial Marketing Management, Vol. 39, No. 1, pp.100-108.

Johnston, R. (1999), "Service transaction analysis: assessing and improving the customer's experience", Managing Service Quality, Vol. 9, No. 2, pp. 102-109.

Johnston, R., Clark, G. and Shulver, M. (2011), Service management, improving service delivery, 4th edition, Harlow, Pearson.

Johnston, R. and Kong, X. (2011), "The customer experience: a road-map for improvement", Managing Service Quality: An International Journal, Vol. 21, No. 1, pp. 5-24.

Joy, A. and Sherry, J.F. (2003), "Speaking of art as embodied imagination: a multisensory approach to understanding aesthetic experience", Journal of Consumer Research, Vol. 30, No. 2, pp. 259-282.

Junginger, S. and Sangiorgi, D. (2011), "Public policy and public management: contextualizing service design in the public sector". In Cooper, R, Junginger, S. and Lockwood, T. (eds) The Handbook of Design Management, Oxford: Berg. pp 480-494.

Kingman-Brundage, J. (1991), “Technology, design and service quality", International Journal of Service Industry Management, Vol. 2, No. 3, pp. 47-59.

Lemke, F., Clark, M. and Wilson, H. (2011), "Customer experience quality: an exploration in business and consumer contexts using repertory grid technique", Journal of the Academy of Marketing Sciences, Vol. 39, No. 6, pp. 846-869.

Levitt, T. (1972), "Production-line approach to service", Harvard business review, Vol. 50, No. 5, pp. 41-52.

Lincoln, Y.S. and Guba, E.G. (1985), Naturalistic inquiry, Sage, Beverley Hills, CA.

Lincoln, Y.S. Lynham, S.A. and Guba, E.G. (2011) "Paradigmatic Controversies, Contradictions and Emerging Confluences, Revisited" in Denzin, N.K. and Lincoln, Y.S. The SAGE Handbook of Qualitative Research, $4^{\text {th }}$ Edition, Sage, London.

Lovelock, C. (1995), "Competing on service: technology and teamwork in supplementary services", Planning Review, Vol. 23, No. 4, pp. 32-47.

Maister, D.H. and Lovelock, C.H. (1982), "Managing facilitator services", Sloan Management Review, Vol. 23, No. 4, pp. 19-31. 
Margolin, V. (1997), “Getting to know the user”, Design Studies, Vol. 18, No. 3, pp. 227-236.

Martin, R.L. (2009) The design of business: why design thinking is the next competitive advantage, Harvard Business School Press, Boston, MA.

Matthyssens, P. and Vandenbempt, K. (2010), "Service addition as business market strategy: identification of transition trajectories", Journal of Service Management, Vol. 21 No. 5, pp. 693714.

Meroni, A., \& Sangiorgi, D. (2011), “A new discipline”. In A. Meroni \& D. Sangiorgi (Eds.), Design for services (pp. 9-33). Aldershot, UK: Gower Publishing.

Miles, M.B. and Huberman, A.M. (1994), Qualitative data analysis, an expanded sourcebook, 2nd ed, Sage, Thousand Oaks, CA.

Morris, B. and Johnston, R. (1987), "Dealing with inherent variability: The difference between manufacturing and service?", International Journal of Operations \& Production Management, Vol. 7, No. 4, pp. 13-22.

Norman, D. (2004), Emotional design: why we love (or hate) everyday things, Basic books, New York, NY.

Patricio, L., Fisk R.P. and e Cunha, J.F. (2008), "Designing Multi-Interface Service Experiences: The Service Experience Blueprint", Journal of Service Research, Vol. 10, No. 4, pp. 318-334.

Payne, A.F. and Holt, S. (2001), "Diagnosing customer value: integrating the value process and relationship marketing”, British Journal of Management, Vol. 12, No. 2, pp. 159-182.

Peirce C.S. (1931) Collected papers, Harvard University Press, Cambridge, MA.

Pine, B.J. and Gilmore, J.H. (1998), "Welcome to the Experience Economy", Harvard Business Review, Vol. 76, No. 4, pp. 97-105.

Pine, B.J. and Gilmore, J.H. (1999), The experience economy: work is theatre and every business a stage, Harvard Business School Press, Boston, MA.

Ponsignon, F., Smart, P.A. and Maull, R.S. (2012), "Process design principles in service firms: Universal or context dependent? A literature review and new research directions", Total Quality Management \& Business Excellence, Vol. 23, No. 11-12, pp. 1273-1296.

Prahalad, C.K., and V. Ramaswamy. (2004). "Co-creation experiences: The next practice in value creation”, Journal of Interactive Marketing, Vol. 18, No. 3, pp.5-14.

Pucillo, F. and Cascini, G. (2014), "A framework for user experience, needs and affordances”, Design Studies, Vol. 35, No. 2, pp. 160-179.

Puccinelli, N.M., Goodstein, R.C., Grewal, D., Price, R., Raghubir, P. and Stewart, D. (2009), "Customer experience management in retailing: understanding the buying process" Journal of Retailing, Vol. 85, No. 1, pp. 15-30.

Pullman, M.E. and Gross, M.A. (2004), "Ability of experience design elements to elicit emotions and loyalty behaviors”, Decision Sciences, Vol. 35, No. 3, pp. 551-578.

Ragin, C.C. (2014), The comparative method: Moving beyond qualitative and quantitative strategies. Univ of California Press.

Redström, J. (2006), "Towards user design? On the shift from object to user as the subject of design", Design Studies, Vol. 27, No. 2, pp. 123-139. 
Rogers, Y., Sharp, H. and Preece, J. (2012), Interaction Design: beyond human-computer interaction, $3^{\text {rd }}$ Edition, Chichester, Wiley.

Roos, I. and Friman, M. (2008), "Emotional experiences in customer relationships - a telecommunication study", International Journal of Service Industry Management, Vol. 19, No. 3, pp. 281-301.

Roth, A.V. and Menor, L.J. (2003), "Insights into Service Service management: A Research Agenda", Production and Operations Management, Vol. 12, No. 2, pp. 145-163.

Roy, R. and Riedel, J.C.K.H. (1997) "Design and innovation in successful product competition." Technovation, Vol.17, No. 10, pp. 537-594.

Sampson, S.E. (2000), "Customer-supplier duality and bidirectional supply chains in service organizations", International Journal of Service Industry Management, Vol. 11, No. 4, pp. 348364.

Sasser, W.E., Olsen, R.P. and Wyckoff, D.D. (1978), Management of service operations: Text, cases, and readings, Allyn \& Bacon.

Stuart, F.I. and Tax, S. (2004), "Toward an integrative approach to designing service experiences: lessons learned from the theatre", Journal of Operations Management, Vol. 22, No. 6, pp. 609627.

Suchman, L. (1987), Plans and situated action, Cambridge University Press, Cambridge.

Tansik, D.A. and Smith, W.L. (2000) „Scripting the service encounter“ in Fitzsimmons, J.A. and Fitzsimmons, M.J. New Service Development: Creating Memorable Experiences, Sage, London.

Vargo, S.L. and Lusch, R.F. (2008), "Service Dominant Logic: continuing the evolution", Journal of the Academy of Marketing Science, Vol. 36, No. 1, pp. 1-10.

Verganti, R. (2009), Design driven innovation - changing the rules of competition by radically innovating what things mean, Harvard Business School Press, Boston, MA.

Verhoef, P.C., Lemon, K.N., Parasuraman, A., Roggeveen, A., Tsiros, M. and Schlesinger, L.A. (2009), "Customer experience creation: Determinants, dynamics and management strategies", Journal of Retailing, Vol. 85, No.1, pp. 31-41.

Voss, C., Tsikriktsis, N. and Frohlich, M. (2003), "Case research in service management", International Journal of Operations \& Production Management, Vol. 22, No. 2, pp. 195-219.

Wetter-Edman, K, Sangiorgi, D, Edvardsson, B, Holmlid, S, Grönroos, C and Mattelmäki, T. (2013) Design for Service comes to Service Logic, The Naples Forum on Service, Naples, Italy, 18th21 st June.

Yin, R.K. (2003), Case study research: design and methods, Sage, Thousand Oaks, CA.

Zomerdijk, L.G. and de Vries, J. (2007), "Structuring front office and back office work in service delivery systems: an empirical study of three design decisions", International Journal of Operations \& Production Management, Vol. 27, No. 1, pp. 108-131.

Zomerdijk, L.G. and Voss, C.A. (2010), "Service design for experience-centric services", Journal of Service Research, Vol. 13, No.1, pp. 67-82.

Zomerdijk, L.G. and Voss, C.A. (2011), "NSD processes and practices in experiential services", Journal of Product Innovation Management, Vol. 28, pp. 63-80. 